\title{
Results from portable and of low cost equipment developed for detection of milk adulterations
}

\author{
Wesley William Gonçalves NASCIMENTO ${ }^{1,2}$, Mariane Parma Ferreira de SOUZA ${ }^{1,2}$, \\ Ana Carolina Menezes Mendonça VALENTE ${ }^{1,2}$, Virgílio de Carvalho dos ANJOS³, \\ Marco Antônio Moreira FURTADO ${ }^{4}$, Maria José Valenzuela BELL ${ }^{3 *}$
}

\begin{abstract}
This work presents the results of a device, MilkTech, developed to detect milk tampering, based on electrical measurements. The device indicates possible frauds by water, sodium chloride, caustic soda, ethyl alcohol and sodium bicarbonate. The advantages in relation to traditional methods are portability, low cost and detection of mixed frauds. The experiments were conducted in dairy plants at Governador Valadares, in Brazil. The results were compared with cryoscopy and chloride tests. It is demonstrated there is high correlation between MilkTech and Cryoscopy. For instance, the detection limit of the equipment for water addition with the set of analyzed data was $0.78 \%$ with precision of $1.1 \%$. Adulterations with sodium chloride, caustic soda, ethyl alcohol and sodium bicarbonate are detected qualitatively, even when added with water, and MilkTech indicates "SUSPECT" milk.
\end{abstract}

Keywords: milk; adulteration; quality control.

Practical Application: Detection of frauds in milk.

\section{Introduction}

Milk is an important food from nutritional, economic and social points of view. Milk presents more than one hundred thousand constituents, possesses many vitamins and minerals (Walstra \& Jenness, 1987). In addition, dairy products are also susceptible to fraud (Hrbek et al., 2014). Moreover, authenticity is an important issue due to the concerns about the safety and quality of food (Zain et al., 2016) and has been discussed worldwide (Souza et al., 2011). The limits for the microbiological, physical and chemical parameters of milk are established by the Brazilian legislation (Brasil, 2002, 2011).

Brazil is one of the largest producers in the world and its production has grown in the last years. However, food adulteration has become more sophisticated in the recent years. Many cases have also been reported in other countries such as China, for example (Zhang \& Xue, 2016). A very common problem is the adulteration of milk by adding substances such as water, sodium chloride, caustic soda, formaldehyde, and so on, that can mask or preserve milk properties as cryoscopy point, acidity, $\mathrm{pH}$, as shown by Furtado \& Vilela (1996). Milk can be adulterated either for financial gain or due to poor hygiene conditions of processing, storage, transportation, and marketing (Handford et al., 2016).

Even though there are recommended methods to evaluate the milk quality, it has been demonstrated that they fail in several situations, especially those with mixed adulterants. Studies on fast, low cost, and nondestructive detection methods for composition/adulterants is becoming essential for food safety and public health (Brandão et al., 2017). In view of this, the milk chain needs new and more efficient processes to ensure the quality and safety of milk (Das et al., 2011).

The official methodology for detecting water addition is cryoscopy, which measures the freezing point of milk. However, this method is reliable only for the detection of water addition, as demonstrated by Nascimento et al. (2013). Other frauds as simultaneous addition of water and sodium chloride (or sucrose or sodium bicarbonate) can mask the cryoscopy index.

In view of these problems, the present work shows the development of a new apparatus, named MilkTech (Patent deposit number PI0805121-6, Brazil), as shown in Figure 1 (MilkTech, 2011).

It is low-cost and portable equipment for milk quality analysis, focused in the detection of the following adulterants: water, sodium chloride, sodium bicarbonate and caustic soda. MilkTech also reports the cryoscopy in an indirect way, from the determined percentage of added water. Small dairy processors would benefit from the equipment since they could use it during the collect of milk and guarantee the quality of milk in a very fast way. Moreover, dairy industries could use it in the milk pick-up truck. So, it may discard the milk before it contaminates the milk already stored.

Milktech proposes a new analytical approach to detect milk adulteration especially with water, based on electrical properties

${ }^{1}$ Departamento de Farmácia, Universidade Federal de Juiz de Fora - UFJF, Campus Governador Valadares, Governador Valadares, MG, Brazil

${ }^{2}$ Instituto de Ciências da Vida, Governador Valadares, MG, Brazil

${ }^{3}$ Departamento de Física, Instituto de Ciências Exatas, Universidade Federal de Juiz de Fora - UFJF, Campus Juiz de Fora, Juiz de Fora, MG, Brazil

${ }^{4}$ Departamento de Farmácia, Faculdade de Farmácia, Universidade Federal de Juiz de Fora - UFJF, Campus Juiz de Fora, Juiz de Fora, MG, Brazil

*Corresponding author: mjbell06@gmail.br 
of milk. From the electrical point of view, milk can be understood as an electrolytic solution in which the charge carriers originate from the dissociation of salts. Therefore, the electrical conductance of milk is mainly attributed to the presence of ions, in particular $\mathrm{Na}+, \mathrm{K}+$ and $\mathrm{Cl}$ - (Walstra \& Jenness, 1987). Some studies relate electrical measurements to quality control and detection of milk fraud, as demonstrated by Mabrook and Petty (Mabrook \& Petty, 2002). Nascimento et al correlated the electrical behavior of milk with the presence of fraudulent substances. Models were proposed to fit the behavior of electrical conductivity with the added substances and statistical tools were used to validate the models (Nascimento et al., 2013).

MilkTech is based on these models. The equipment is portable, allowing the use in the field, during the milk collection. It operates from two microprocessors, one for the generation and processing of the signals, as well as calculations while the other is for control and management of the involved functions. Data is archived and analyzed, and the equipment furnishes complete reports.

In this paper we will present results obtained from this equipment in comparison with Cryoscopy and chloride test. The experiments were carried out in the laboratory and farms in Governador Valadares, Brazil.

\section{Materials and methods}

The experiments were performed with raw milk collected from Embrapa Dairy Cattle (in Coronel Pacheco, Minas Gerais, Brazil) with the following physic-chemical parameters: Acidity 14-18 ${ }^{\circ}$ Dornic, density between $1.028 \mathrm{~g} \cdot \mathrm{mL}^{-1}$ and $1.032 \mathrm{~g} \cdot \mathrm{mL}^{-1}$ and cryoscopy index $-0.530{ }^{\circ} \mathrm{H}$, all in accordance with the Brazilian legislation.

Raw milk was adulterated at pre-defined concentrations with tap water, sodium chloride, sodium bicarbonate, sodium hydroxide and alcohol purchased from the trade. Parametric Tests (after verification of the assumptions) were applied from

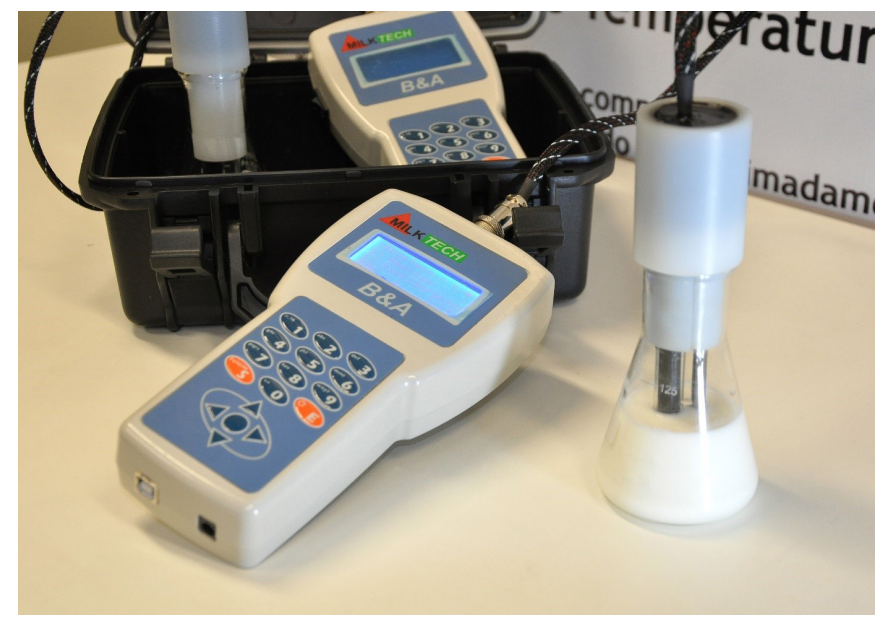

Figure 1. Milktech apparatus. It contains an electrode and a temperature sensor, so measurements are temperature compensated. The display shows the following information: Added water in \% (if any) and cryoscopy. When some reconstituting is detected, the display exhibits the message: "SUSPECT", milk added with reconstituting or high acidity. the results generated. Field analyzes using the equipment were also performed in Governador Valadares to evaluate the behavior of MilkTech and the methodology based on Electrical measurements in a real environment. Periodic analyzes were performed in identified samples from each producer. Analyzes were performed simultaneously with the cryoscopy method. In samples that showed a reconstitution or high acidity by MilkTech were performed Dornic acidity tests and chloride detection.

\section{Results and discussion}

In previous studies, a statistical evaluation and validation of the descriptive/predictive model used by MilkTech was performed (Nascimento et al., 2013). After the regression using the least squares method based on the experiment, the model did not show a lack of fit in the linear model adjusted with $95 \%$ confidence and normality (Kolmogorov-Smirnov), Homoscedasticity (Levene), autocorrelation (Durbin-Watson), with $95 \%$ confidence. The P-values found were, respectively, 0.200 , 0.516 and 2.009, that demonstrated the model is appropriate.

In this work, to verify the efficiency and robustness of the model used by MilkTech, a comparative study was performed. Several adulterants were used: water, caustic soda, salt, alcohol and sodium bicarbonate.

First, we show the results obtained with water addition, as presented in Table 1. Samples (raw milk) were prepared with seven different levels of water addition, up to $26 \%$ and tested with Milktech.

According to Table 1, the results obtained with MilkTech were consistent with the actual dilution levels of water. The assumption of normality was tested. It was not observed deviation from normality, with $95 \%$ confidence, by the application of the Shapiro-Wilk test, since the p-value was equal to 0.29 . The T-test was also performed and there was no significant difference for the total set of samples with $96 \%$ confidence. The p-value was 0.041 . The detection limit of the equipment was $0.78 \%$ of water with an accuracy of $1.1 \%$.

MilkTech was also tested with raw milk adulterated with sodium chloride and sodium bicarbonate. Similarly to the experiments with added water, different levels of sodium chloride and sodium bicarbonate were used, and a linear calibration for each adulterant was established. The results showed that the equipment detects these adulterants, with detection limits of $0.09 \mathrm{~g} / \mathrm{L}$ for sodium chloride and $0.27 \mathrm{~g} / \mathrm{L}$ for sodium bicarbonate. It is important to note that Milktech does not discriminate between sodium chloride and sodium bicarbonate, but it detects both as "reconstituents" (see Table 2).

Raw milk with sodium hydroxide and ethyl alcohol were also prepared, with concentrations as shown in Table 2.

The results showed that the equipment is sensitive to small addition of $\mathrm{NaOH}, \mathrm{NaCl}$ and ethyl alcohol, and quantifies water addition (in \%).

In dairy farms, Milktech also showed effective performance. Analyzes were carried out in a cooperative and a dairy industry 
Table 1. Milktech tests in 7 samples adulterated with water (in \%), from 0 to $26 \%$. Second column shows the actual $\%$ of added water, while the third one exhibits the result obtained with Milktech.

\begin{tabular}{ccc}
\hline Sample & $\begin{array}{c}\text { Water Addition } \\
(\%)\end{array}$ & $\begin{array}{c}\text { Water addition detected by } \\
\text { MilkTech (\%) }\end{array}$ \\
\hline & & \\
2 & 0 & 0.1 \\
3 & 14 & 13.3 \\
4 & 3 & 2.5 \\
5 & 7 & 6.2 \\
6 & 11 & 10.9 \\
7 & 20 & 19.6 \\
\hline
\end{tabular}

Table 2. MilkTech performance compared with Cryoscopy in raw milk samples adulterated with water, sodium chloride, sodium hydroxide (caustic soda) and ethyl alcohol.

\begin{tabular}{ccccc}
\hline Sample & Adulteration & Quantity & $\begin{array}{c}\text { CRYOSCOPY } \\
(\text { MilkTech }) \\
\left({ }^{\circ} \mathrm{H}\right)\end{array}$ & MILKTECH \\
\hline $\mathbf{0}$ & - & $0 \%$ & -0.540 & OK \\
$\mathbf{1}$ & Water & $3 \mathrm{~mL} / \mathrm{L}$ & -0.539 & $0.2 \%$ \\
$\mathbf{2}$ & Water & $10 \mathrm{~mL} / \mathrm{L}$ & -0.536 & $0.8 \%$ \\
$\mathbf{3}$ & $\mathrm{NaCl}$ & $0.1 \mathrm{~g} / \mathrm{L}$ & -0.575 & $\begin{array}{c}\text { Reconstituting } \\
\text { addition or high } \\
\text { acidity }\end{array}$ \\
& & & & $\begin{array}{c}\text { Reconstituting } \\
\text { addition or high } \\
\text { acidity }\end{array}$ \\
$\mathbf{4}$ & NaOH (P.A.) & $0.1 \mathrm{~g} / \mathrm{L}$ & -0.574 & $\begin{array}{c}\text { Suspect } 0.2 \% \\
\text { (P.M.:40,00) }\end{array}$ \\
& & & -0.539 & Suspect $1.3 \%$ \\
$\mathbf{5}$ & Ethyl & $0.8 \mathrm{~mL} / \mathrm{L}$ & & \\
& Alcohol & & & \\
& (98.5 GL) & & &
\end{tabular}

Table 3. Comparison of cryoscopy values by the official method and MilkTech in a cooperative of Governador Valadares MG.

\begin{tabular}{ccccc}
\hline Sample & $\begin{array}{c}\text { CRYOSCOPY } \\
\left({ }^{\circ} \mathrm{H}\right) \\
(\text { CRIOSCOPY) }\end{array}$ & $\begin{array}{c}\text { CRYOSCOPY } \\
\left({ }^{\circ} \mathrm{H}\right) \\
(\text { MilkTech) }\end{array}$ & $\begin{array}{c}\text { CONCLUSION } \\
(\text { MilkTech) }\end{array}$ & $\begin{array}{c}\text { CHLORIDE } \\
\text { TEST }\end{array}$ \\
\hline $\mathbf{1}$ & -0.539 & -0.546 & REGULAR & \\
$\mathbf{2}$ & -0.537 & -0.542 & REGULAR & \\
$\mathbf{3}$ & -0.537 & -0.542 & REGULAR & \\
$\mathbf{4}$ & -0.535 & -0.542 & REGULAR & \\
$\mathbf{5}$ & -0.538 & -0.545 & REGULAR & \\
$\mathbf{6}$ & -0.535 & -0.540 & OK & \\
$\mathbf{7}$ & -0.538 & -0.540 & OK & \\
$\mathbf{8}$ & -0.546 & -0.540 & OK & \\
$\mathbf{9}$ & -0.538 & -0.542 & REGULAR & \\
$\mathbf{1 0}$ & -0.526 & - & SUSPECT & POSITIVE \\
$\mathbf{1 1}$ & -0.538 & -0.548 & REGULAR & \\
$\mathbf{1 2}$ & -0.541 & - & SUSPECT & POSITIVE \\
\hline
\end{tabular}

in Governador Valadares, shown in Tables 3 and 4, respectively. Although the physical property used by Milktech is not a freezing point, there was a good correlation of the cryoscopy results.
Table 4. Comparison of cryoscopy values by the official method and MilkTech in a dairy industry of Governador Valadares, Brazil.

\begin{tabular}{cccc}
\hline SAMPLE & $\begin{array}{c}\text { CRYOSCOPY }\left({ }^{\circ} \mathrm{H}\right) \\
\text { (Cryoscopy) }\end{array}$ & $\begin{array}{c}\text { CRYOSCOPY }\left({ }^{\circ} \mathrm{H}\right) \\
(\text { MilkTech })\end{array}$ & SITUATION \\
\hline $\mathbf{1}$ & -0.542 & -0.540 & OK \\
$\mathbf{2}$ & -0.540 & -0.540 & OK \\
$\mathbf{3}$ & -0.523 & -0.540 & OK \\
$\mathbf{4}$ & -0.538 & -0.539 & REGULAR \\
$\mathbf{5}$ & -0.458 & - & $16.4 \%$ \\
$\mathbf{6}$ & -0.523 & - & $3.4 \%$ \\
$\mathbf{7}$ & -0.540 & -0.540 & OK \\
$\mathbf{8}$ & -0.542 & -0.540 & OK \\
$\mathbf{9}$ & -0.540 & -0.540 & OK \\
$\mathbf{1 0}$ & -0.544 & -0.540 & OK \\
$\mathbf{1 1}$ & -0.548 & -0.543 & REGULAR \\
$\mathbf{1 2}$ & -0.542 & -0.540 & OK \\
$\mathbf{1 3}$ & -0.542 & -0.540 & OK \\
$\mathbf{1 4}$ & -0.542 & -0.542 & REGULAR \\
$\mathbf{1 5}$ & -0.542 & -0.540 & REGULAR \\
$\mathbf{1 6}$ & 0.542 & -0.544 & REGULAR \\
$\mathbf{1 7}$ & -0.542 & -0.542 & REGULAR \\
$\mathbf{1 8}$ & -0.542 & -0.540 & OK \\
$\mathbf{1 9}$ & -0.542 & -0.540 & OK \\
$\mathbf{2 0}$ & -0.542 & -0.540 & OK \\
$\mathbf{2 1}$ & -0.542 & -0.479 & SUSPECT \\
$\mathbf{2 2}$ & -0.542 & -0.540 & OK \\
$\mathbf{2 3}$ & -0.540 & -0.540 & OK \\
$\mathbf{2 4}$ & -0.362 & -0.386 & $40.44 \%$ \\
$\mathbf{2 5}$ & -0.537 & -0.540 & OK \\
$\mathbf{2 6}$ & -0.537 & -0.540 & OK \\
$\mathbf{2 7}$ & -0.537 & -0.540 & OK \\
\hline & & & \\
\hline
\end{tabular}

Milktech gives cryoscopy index in an indirect way, through the determination of the water addition. It is important to emphasize the samples were Milktech indicated adulteration. In these cases the samples were considered SUSPECT by Milktech, although they were not detected by the cryoscopy. For instance, Samples 10 and 12 were submitted to chlorides test and the results attested the presence of sodium chloride confirming the suspicion of Milktech. This is a typical mixed fraud involving water and sodium chloride, which preserves the cryoscopy index, but alters the electrical properties of milk. For future experiments our proposal will be to carry out complementary tests.

\section{Conclusions}

Milktech presented satisfactory results for detection of the tested adulterants. The linear models used for each adulterant exhibited no lack of adjustment for a range of confidence of $96 \%$. MilkTech's detection limits for water, sodium chloride and sodium bicarbonate were $0.78 \%, 0.09 \mathrm{~g} / \mathrm{L}$ and $0.27 \mathrm{~g} / \mathrm{L}$, respectively. In comparison with the actual values, no significant differences were observed for a confidence interval of $95 \%$. Therefore, the advantages of the technique based on electrical measurements are numerous: low cost, portability and fast analysis. Milktech can be used in quality control and fraud detection, simultaneously with reference methods. Even though Milktech cannot discriminate 
all adulterants, it can quantify water addition. On the other hand, it is able to detect qualitatively caustic soda, sodium bicarbonate, sodium chloride and ethyl alcohol.

\section{Acknowledgements}

The authors would like to thank the Brazilian agencies CAPES, CNPq, FAPEMIG for financial support and UFJF and EMBRAPA Dairy Cattle.

\section{References}

Brandão, M. P., Gouvea, M. No., Anjos, V. C., \& Bell, M. J. V. (2017). Detection of adulteration of goat milk powder with bovine milk powder by front-face and time resolved fluorescence. Food Control, 81, 168-172. http://dx.doi.org/10.1016/j.foodcont.2017.06.008.

Brasil, Ministério da Agricultura, Pecuária e Abastecimento. Departamento de Inspeção de Produtos de Origem Animal. (2002, September 20). Aprova os regulamentos técnicos de produção, identidade e qualidade do leite tipo A, do leite tipo B, do leite tipo C, do leite pasteurizado e do leite cru refrigerado e o regulamento técnico da coleta de leite cru refrigerado e seu transporte a granel, em conformidade com os anexos a esta Instrução Normativa (Instrução Normativa $n^{\circ}$ 51, de 18 de setembro de 2002). Diário Oficial [da] República Federativa do Brasil, seção 1, p. 13.

Brasil, Ministério da Agricultura, Pecuária e Abastecimento. (2011, December 29). Oficializa os métodos analíticos oficiais físicoquímicos, para controle de leite e produtos lácteos (Instrução Normativa $n^{\circ} 62$, de 29 de dezembro de 2011). Diário Oficial [da] República Federativa do Brasil.

Das, S., Sivaramakrishna, M., Biswas, K., \& Goswami, I. (2011). Performance study of a constant phase angle based impedance sensor to detect milk adulteration. Sensors and Actuators A, Physical, 167(2), 273-278. http://dx.doi.org/10.1016/j.sna.2011.02.041.

Furtado, M. A. M., \& Vilela, M. A. P. (1996). Fraudes em leite de consumo: limites de detecção. Revista Leite e Derivados, 29, 14-18.
Handford, C. E., Campbell, K., \& Elliott, C. T.. (2016). Impacts of milk fraud on food safety and nutrition with special emphasis on developing countries. Comprehensive Reviews in Food Science and Food Safety, 15(1), 130-142. http://dx.doi.org/10.1111/1541-4337.12181.

Hrbek, V., Vaclavik, L., Elich, O., \& Hajslova, J. (2014). Authentication of milk and milk-based foods by direct analysis in real time ionizationhigh resolution mass spectrometry (DART-HRMS) technique: a critical assessment. Food Control, 36(1), 138-145. http://dx.doi. org/10.1016/j.foodcont.2013.08.003.

Mabrook, M. F., \& Petty, M. C. (2002). Application of electrical admittance measurements to the quality control of milk. Sensors and Actuators. B, Chemical, 84(2-3), 136-141. http://dx.doi.org/10.1016/ S0925-4005(02)00014-X.

Milktech. (2011). Trade mark: RPI n 2138, 27/12/2011. Patent PI0805121-6 A2. Brasília: INPI.

Nascimento, W. W. G., Oliveira, M. A. L., Furtado, M. A. M., Anjos, V. C., \& Bell, M. J. V. (2013). Development and optimization of an alternative methodology for detection of milk adulteration by water. Journal of Food Science and Engineering, 3, 363-370.

Souza, S. S., Cruz, A. G., Walter, E. H. M., Faria, J. A. F., Celeghini, R. M. S., Ferreira, M. M. C., Granato, D., \& Sant'Ana, A. S. (2011). Sant'Ana, A de S. (2011). Monitoring the authenticity of Brazilian UHT milk: A chemometric approach. Food Chemistry, 124(2), 692695. http://dx.doi.org/10.1016/j.foodchem.2010.06.074.

Walstra, P.; Jenness, R. (1987). Quimica y fisica lactologica. Zaragoza: Acribia S. A.

Zain, S. M., Behkami, S., Bakirdere, S., \& Koki, I. B. (2016). Milk authentication and discrimination via metal content clustering: a case of comparing milk from Malaysia and selected countries of the world. Food Control, 66, 306-314. http://dx.doi.org/10.1016/j. foodcont.2016.02.015.

Zhang, W., \& Xue, J. (2016). Economically motivated food fraud and adulteration in China: an analysis based on 1553 media reports. Food Control, 67, 192-198. http://dx.doi.org/10.1016/j.foodcont.2016.03.004. 